\title{
Factors Influencing the Labor Force Participation of Married Women in the United States
}

\author{
Rewat Thamma-Apiroam ${ }^{1}$ \\ ${ }^{1}$ Department of Economics, Faculty of Economics, Kasetsart University, Bangkok, Thailand \\ Correspondence: Rewat Thamma-Apiroam, Department of Economics, Faculty of Economics, Kasetsart \\ University, Bangkok, 10900, Thailand. Tel: 662-579-8739. E-mail: fecoret@hotmail.com
}

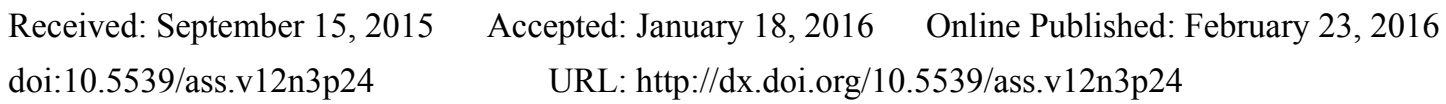

\begin{abstract}
This paper examines the factors that influence the labor force participation of married women in the United States during 1975-2002, using multiple regressions with log specification. The results show that women earnings and life expectancy of women are not satisfactory indicators of whether married women should join the labor force. Nonetheless, there exist strong relationships between the decisions to work and men's income, unemployment rate, consumer durable goods to GDP ratio, women's schooling as well as divorce rate.
\end{abstract}

Keywords: labor force participation, married women, influencing factors, the United States of America

\section{Introduction}

What affects the married women's decision to join the labor force keeps revolving overtime. Studying women's labor supply basically involves the women's wage rates, husband's incomes and divorce rate as crucial factors influencing whether or not the women decide to join the labor force. In the past, during the war time, one of the obvious reasons why women including married women went out to work was due to the labor shortage. Women's share of the labor force rose from 12 to 18 million under the pressure of wartime demand. However, after the 70 's, consumer products, especially durable goods such as washing machine, refrigerator, microwave oven, facilitating household production were increasingly accepted as a significant cause of women's working. In addition, women schooling, access to public health of women and contraception use of married women are anticipated to play such important roles.

Several studies had been conducted in order to answer this topical question by using cross-sectional data, but they did not account for the labor force participation behaviors of married women over time, in particular after the 70's when high-technology consumer durable products were introduced. Mincer (1962) used a single equation model to investigate factors determining married women's labor force participation in 57 large northern standard metropolitan areas in 1950. He found that wives' wages have a positive relationship with the labor force participation but husband's incomes determine the labor force participation of wives negatively. Moreover, unemployment deters the labor force participation. Cain, Bowen and Finegan (1970) repeated Mincer's study with more recent data and they found the same relationships but weaker effects. These studies imply that wives' wages determine the labor force participation decreasingly over time. Fields (1976) also found weak effects of wives' wages on the participation and mentioned that "women were significantly changing their work role orientation." Furthermore, one of the Fraundorf's findings (1979) is that "the availability of jobs was more important than high wages in inducing women to seek work." By employing multiple regressions using women's earnings and family income together with other independent variables, she found that women's earnings are not a factor determining women labor force participation. Subsequently, a time-series analysis by O'Neill (1981) includes other variables such as divorce rate, industrial structure index, and children ever born, into the regression. Her major finding is that women's wages and men's income still determine the labor force participation of women and married women during 1948-1978. Unemployment rate has a negative relationship with the participation while divorce rate and industrial structure index imply a positive relationship. Rather than using single equation model, Fleisher and Rhodes (1976) make use of simultaneous equations model (two stages least squares) to examine the relationships between unemployment rates and the labor force participation of married women. They found no relation between these two variables but if Ordinary Least Squares (OLS) estimation is used instead, a strongly negative relationship is present. 
Unlike previous studies using cross-sectional data, O'Neill (1981) challenges other findings by applying time-series analysis to her study to investigate the behaviors of women and married women in joining the labor market over time. She asserted that time series analyses had been avoided mainly because of two reasons. One is lack of data and the other is owing to a belief that tastes and attitudes of married women towards working change through time. However, the data today is readily accessible and the tastes as well as attitudes cannot be measured, so this present study ignores that belief and assumes the tastes and attitudes toward working remain unchanged.

Another important factor anticipated to perform well in explaining the labor force participation is divorce rate. As the divorce rate soars, married women tend to depend on themselves as well as responsibilities and seeking income for the family become increasingly unavoidable and this leads to the decisions to join the labor market. Consumer culture is a typical reason why married women have to join the labor force. Families need more income to buy new goods like washing machines, dryers, dishwashers, microwaves, refrigerators, vacuum cleaners and other appliances. These consumer durable goods play a paramount role in substituting home-made production. Women have more free time and in a sense are liberated, so they decide to join the labor market. The reason for this is supported by numerous studies such as Fraundrof (1979), O’Neill (1981) and Khan (2004). Greenwood, Seshadri and Yorukoglu (2005) developed a sophisticated model using dynamic general equilibrium framework to explain the impact of consumer durable goods on whether married women should work. Similar to other studies, they found that with the advent of these time- and labor-saving machines, women and married women are "liberated" and this affects the decisions to work of married women in a positive way. Undoubtedly, rising in labor force participation can be safely delineated by the increasing number of these types of durable goods along with the declines in their prices through time.

Women's schooling and access to public health including contraception use are all expected to have a positive relationship with the labor force participation of married women. Better education will make a difference. In the 1950 s, more than half of the women who reached the age of 35 at least had graduated from high schools and the average number of years at school of women had continuously risen from 13.78 years in 1975 to 15.51 years in 1990 and to 16.66 years in 2002. This makes women and married women more competitive to the labor market. They prompt for higher levels of jobs such as managers, educators and physicians. This situation also coincides with a study by Welch (2000). He pointed out that as the relative wages of women rise and the growth of women's education has outstripped that of men's, women's job positions are increasingly replacing those traditionally dominated by men. Better Access to public health increases women's life expectancy from 59.8 years in 1975 to 71.90 years in 1990 and to 77.90 years in 2002. Such increase implies that the average woman can look forward to at least a decade of relatively free time once their children were in school. With technological, educational and medical advances, contraception equips women to complete their child bearing at younger ages, thus leading to more free time to work outside.

The bottom line is that married women as a large part of women labor force have decided to join the labor market but why it is so is the question that this paper intends to answer. Moreover, controversial issues about women's earnings discussed earlier have induced me to search for the answer by using time-series data analysis. Even though factors are same as those factors used to explain why women want to work, some factors presumably are different due to the nature of married women. These might be the ages of children, access to public health and contraception use. Therefore, this paper examines the labor force participation behavior of married women in the United States over the period of study.

The rest of this paper is organized as follows. The method, model specification, and data are described in the next section. It includes the sources of data, periods of data observed, and data description. The next section presents the results. And the last section is discussion and conclusion.

\section{Method and Data}

As aforementioned, this study aims at identifying variables that explain the dependent variables, the labor force participation of married women and determining the nature of relations of these variables. To achieve the objective, first is running a regression using all labor force participation rates of married women as the dependent variable along with potential independent variables. Second is separating the labor force participation of married women into sub-groups by children ages - under 3 years old, under 6 years old, between 6 and 17 years old, under 18 years old and 18 years old or older - because different ages of children might influence the working behavior. That is, a stronger relationship (or a weaker relationship in some cases) is expected with the increasing ages of children. The following multiple regression model is proposed.

$$
\begin{gathered}
\ln M W=\alpha_{0}+\alpha_{1} \ln W E+\alpha_{2} \ln M I+\alpha_{3} \ln U N+\alpha_{4} \ln D I V+\alpha_{5} \ln D U R+\alpha_{6} \ln S C H \\
+\alpha_{7} \ln L I F+\alpha_{8} \ln T I M+\varepsilon,
\end{gathered}
$$


where the variables are as follows: MW is labor force participation rates of married women. WE is women's earnings. MI is men's income. UN is unemployment rate. DIV is divorce rate. DUR is durable good consumption to gross domestic products ratio. SCH is years at school of women. LIF is life expectancy of women. TIM is time trend and $\varepsilon$ is the error term.

However, this paper also replaces women's earnings and men's income by women to men wages ratio to find if any improvement of the regression is possible. Having done this, it is believed that the wage ratio between women and men might be a good candidate in explaining the behavior of married women in the labor force. Thus, a similar model with slight modification is proposed.

$$
\begin{gathered}
\ln M W=\beta_{0}+\beta_{1} \ln W R+\beta_{2} \ln U N+\beta_{3} \ln D I V+\beta_{4} \ln D U R+\beta_{5} \ln S C H+\beta_{6} \ln L I F \\
+\beta_{7} \ln T I M+\eta,
\end{gathered}
$$

where WR is the wage ratio of women to men and $\eta$ is the error term while other variables are the same.

The data sources and the details of variables employed in this study are as follows. Labor force participation rates of married women: by marital status, sex, and age, the civilian non-institutional population 16 years old and over and annual averages of monthly figures are from US Bureau of Labor Statistics. Women's earnings: median usual earnings of full-time wage and salary workers in 100's 2005 dollars are also from US Bureau of Labor Statistics. Women-men wage ratio: median usual earnings of full-time wage and salary workers in 100's 2005 dollars are from Women in the Labor Force: a Data Book 2005, US Bureau of Labor Statistics. Men's income: people by mean income and sex in 2005 dollars is from U.S. Census Bureau, Current Population Survey, Annual Social and Economic Supplements. Unemployment rates: unemployment as a percent of the total, 16 years and over civilian labor force are from US Bureau of Labor Statistics. Divorce rates: rate per 1,000 population included reported annulments and some estimated state figures for all years. During 1998-2001, divorce rate excluded data for California, Colorado, Indiana, and Louisiana; population for this rate also excluded these states. In 2004, divorce rates excluded data for California, Georgia, Hawaii, Indiana, and Louisiana. (U.S. National Center for Health Statistics, Vital Statistics of the United States, Annual, National Vital Statistics Reports (NVSR), and unpublished data). Durable goods-GDP ratio: current-historical-cost investment in consumer durable goods as a ratio of GDP is from Bureau of Economic Analysis. Years at school of women: years of school completed by people 25 years and over, by age and sex from 1947, and 1952 to March 2002 are from Current Population Survey, and 2003, 2004, and 2005 are from Annual Social and Economic Supplement to the Current Population Survey (Noninstitutionalized population, excluding members of the Armed Forces living in barracks), 1960 Census of Population, 1950 Census of Population, and 1940 Census of Population (resident population) are from US Census Bureau. Life expectancy as a proxy for access to public health: life expectancy at birth, at 65 years of age, and at 75 years of age, by race and sex, annual averages of monthly figures, populations for computing life expectancy for 1991-1999 are 1990-based post censual estimates of U.S. resident population, which are from Centers for Disease Control and Prevention, National Center for Health Statistics.

\section{Results}

Even though numerous studies on labor supply functions of married women have been conducted by using cross-sectional data, this paper uses time-series analysis for the same issue because doing so would allow one to understand the behaviors of married women in the labor market over time. The results of regressing 28 annual observations of women's labor force participation rates on women's earnings, men's income, unemployment rate, divorce rate, durable goods to GDP ratio, years at school of women, life expectancy as a proxy for access to public health and time trend for the period 1975-2002 are reported as well. Then, after replacing women's earnings and men's income by women-men wage ratio while retaining other variables in the model, the results are somewhat different. The model was estimated for all married women and for married women, separately by children age groups, below 3, below 6, 6-17, below 18 and 18 or older. Changes in labor force participation of married women over this period varied among the children age groups. The participation rate difference in the children age group below 3 and that of over 18 was approximately 4 percentage points in 1975 . However, this difference shrank to about 1 percentage point in 2002. This implies that the participation rates are dependent upon the ages of children. As the data suggested, in the past, married women were likely to stay home, take care of their young children but increasingly seek to work when they have older children but nowadays, the ages of children are less important in determining married women's working. The rational for choosing two basic variables, women's earnings and men's income, is mentioned earlier. The unemployment rate is used as an approximation of purely cyclical disturbances. The divorce rate is included as a proxy for the risk of losing the "job" of wives. The reason why consumer durable goods to GDP ratio and years at school of women are included into the model is elaborated previously as well. Life expectancy of women is added as a proxy for 
access to public health since medical advances and better access to health services might be reflected by longer life expectancy. This paper also includes a linear time trend into the analysis. Doing so is to prevent variables such as wages and incomes, which increase over time, will merely reflect the trend.

For the labor force participation of all married women and married women separated by children age groups as the dependent variables, the regression analysis results are shown in Table 1.

Table 1. Regression of labor force participation rates of all married women and married women, by children ages, 1975-2002

\begin{tabular}{|c|c|c|c|c|c|c|c|c|c|c|}
\hline & $\begin{array}{l}\text { Women } \\
\text { Earnings }^{\mathrm{a}}\end{array}$ & $\begin{array}{c}\text { Men } \\
\text { Income }\end{array}$ & $\begin{array}{c}\text { Unemployment } \\
\text { Rate }\end{array}$ & $\begin{array}{c}\text { Divorce } \\
\text { Rate }\end{array}$ & $\begin{array}{c}\text { Durable } \\
\text { Ratio }\end{array}$ & $\begin{array}{c}\text { Years } \\
\text { at School }\end{array}$ & $\begin{array}{c}\text { Life } \\
\text { Expectancy }\end{array}$ & $\begin{array}{l}\text { Time } \\
\text { Trend }\end{array}$ & $\begin{array}{c}\text { Adjusted } \\
\mathrm{R}^{2}\end{array}$ & D.W. \\
\hline $\begin{array}{l}\text { All married } \\
\text { women }\end{array}$ & $\begin{array}{c}0.02 \\
(0.10)\end{array}$ & $\begin{array}{c}-0.38 \\
(-2.15)\end{array}$ & $\begin{array}{c}-0.07 \\
(-2.12)\end{array}$ & $\begin{array}{c}0.07 \\
(0.49)\end{array}$ & $\begin{array}{c}0.30 \\
(3.14)\end{array}$ & $\begin{array}{c}2.03 \\
(5.84)\end{array}$ & $\begin{array}{c}-1.31 \\
(-1.19)\end{array}$ & $\begin{array}{c}0.04 \\
(2.24)\end{array}$ & 0.990 & 1.38 \\
\hline \multicolumn{11}{|c|}{ Married women with: } \\
\hline Children $<3$ & $\begin{array}{c}-0.10 \\
(-0.47)\end{array}$ & $\begin{array}{c}-0.37 \\
(-1.69)\end{array}$ & $\begin{array}{c}-0.15 \\
(-3.67)\end{array}$ & $\begin{array}{c}0.09 \\
(0.49)\end{array}$ & $\begin{array}{c}0.48 \\
(4.03)\end{array}$ & $\begin{array}{c}2.21 \\
(5.15)\end{array}$ & $\begin{array}{c}-1.36 \\
(-1.00)\end{array}$ & $\begin{array}{c}0.06 \\
(-3.04)\end{array}$ & 0.991 & 1.77 \\
\hline Children $<6$ & $\begin{array}{c}-0.10 \\
(-0.54)\end{array}$ & $\begin{array}{c}-0.36 \\
(-1.79)\end{array}$ & $\begin{array}{c}-0.14 \\
(-3.70)\end{array}$ & $\begin{array}{c}0.04 \\
(0.23)\end{array}$ & $\begin{array}{c}0.56 \\
(5.18)\end{array}$ & $\begin{array}{c}2.06 \\
(5.25)\end{array}$ & $\begin{array}{c}-0.91 \\
(-0.74)\end{array}$ & $\begin{array}{l}-0.05 \\
(2.97)\end{array}$ & 0.992 & 1.88 \\
\hline $\begin{array}{l}\text { Children } \\
<6-17\end{array}$ & $\begin{array}{c}0.01 \\
(0.05)\end{array}$ & $\begin{array}{c}-0.35 \\
(-2.28)\end{array}$ & $\begin{array}{l}-0.12 \\
(-4.01)\end{array}$ & $\begin{array}{c}0.10 \\
(0.85)\end{array}$ & $\begin{array}{c}0.40 \\
(4.88)\end{array}$ & $\begin{array}{c}2.26 \\
(7.54)\end{array}$ & $\begin{array}{l}-1.69 \\
(-1.79)\end{array}$ & $\begin{array}{c}0.03 \\
(2.11)\end{array}$ & 0.993 & 1.85 \\
\hline $\begin{array}{l}\text { Children } \\
<18\end{array}$ & $\begin{array}{l}-0.08 \\
(-0.59)\end{array}$ & $\begin{array}{c}-0.32 \\
(-2.24)\end{array}$ & $\begin{array}{l}-0.12 \\
(-4.54)\end{array}$ & $\begin{array}{c}0.09 \\
(0.76)\end{array}$ & $\begin{array}{c}0.46 \\
(5.90)\end{array}$ & $\begin{array}{c}2.18 \\
(7.81)\end{array}$ & $\begin{array}{l}-1.19 \\
(-1.35)\end{array}$ & $\begin{array}{c}0.04 \\
(2.96)\end{array}$ & 0.995 & 1.80 \\
\hline $\begin{array}{l}\text { Children } \\
<18+\end{array}$ & $\begin{array}{c}0.04 \\
(0.20)\end{array}$ & $\begin{array}{c}-0.48 \\
(-2.43)\end{array}$ & $\begin{array}{l}-0.13 \\
(-3.54)\end{array}$ & $\begin{array}{c}0.05 \\
(0.33)\end{array}$ & $\begin{array}{c}0.39 \\
(3.64)\end{array}$ & $\begin{array}{c}2.05 \\
(5.27)\end{array}$ & $\begin{array}{l}-1.07 \\
(-0.88)\end{array}$ & $\begin{array}{c}0.04 \\
(2.46)\end{array}$ & 0.991 & 1.41 \\
\hline
\end{tabular}

Note: 1 . Coefficients are shown below each variable but intercepts are not shown.

2. $t$-values in parentheses

${ }^{a}$ shown in hundreds of 1975 dollars

According to Table 1, women's earnings is not a significant factor in determining the participation and sometimes even have a negative relationship with the participation. The result comes as a surprise at first but when taking a closer look; this is possible because the wage is only one factor influencing the decision to work. Other essential factors such as leisure are also taken into account. Married women have to decide how much to work and how much not to work (leisure). As the women wages soar continuously during the period of the study, the income effect grows stronger and even offsets the substitution effect. Thus, wages might not play an important role in this case and even have a negative effect when the wages rise. Married women may consider working less due to higher income effect. The labor supply known as "the backward bending supply of labor" might be happening. In addition, the excessive tax burden might account for this phenomenon as well. As wages of married women rise together with the husband's income, higher levels of tax burden deter the working of married women. This finding coincides with Fraundorf's study in 1979 that found no relationship or even negative ones between women's earnings and the participation of married women in the labor force. Men's income has the expected negative effect and the results are at least $10 \%$ level of statistical significance but mostly at $5 \%$. The coefficient for men's income is somewhat lower with the children aged below 18 compared with the children aged 18 or older. This means that the effect is stronger with higher ages of children as expected. Married women have more free time to work outside. Unemployment rate has the anticipated negative effect with highly statistical significance at the $1 \%$ level for all groups. It showed no evidence that sub-groups of married women by children ages are different in coefficients, ranging from -0.15 to -0.12 . Nevertheless, as in cross-sectional studies, the unemployment rate typically has a negative effect but is seldom statistically significant. Divorce rate in this study shows a positive relationship with the labor force participation for all married women and each sub-group of married women but generally not statistical significant. Divorce rates 
during the period 1975-2002 are quite stable and tend to decrease little since 1987. As mentioned earlier, divorce rate is employed as a proxy for the risk of losing the "job" of wives. That is, the divorce rate raises the proportion of women that have to support themselves and their children.

Another imperative factor, durable goods to GDP ratio, has an expected positive effect with highly statistical significance, at the $5 \%$ level for all groups. This is typical because more durable goods consumption implies time and labor-saving for home-produced services which become relatively cheaper, resulting in more available time to work outside. My finding coincides with a large number of studies either using cross-sectional data or time-series data. Focused on this present study, the coefficients are strongest with the married women who have children aged below 6 . This might happen as a consequence of the following. At this age, the time to school just gets started for children, so the mothers even have more free time than before, thus joining the labor force.

Years at school of women play a crucial role in the participation decision and this variable has an expected positive effect with highly statistical significance at the $1 \%$ level but there are no clear participation patterns of different sub-groups. Obviously, higher level of education makes women more competitive and they are increasingly accepted in the workplace. This even shifts the job position to a higher level. Expectancy rate as an approximation of access to public health is projected to have a positive impact on the participation rate; nevertheless, the statistically insignificant results from this variable and the negative coefficients for all groups come as a surprise. This might be corrected if other proxies such as death rate or infant mortality are used instead but due to time constraint, it is left for future research. The time trend variable is positively related to the participation with strongly statistical significance at the $5 \%$ level or better for all groups.

Since the statistical insignificances of women earnings are present, this paper decides to replace women's earnings and men's income with the women-men wage ratio in an attempt to find if any improvements are possible. Then, after running the regression again, the results are presented in Table 2.

Table 2. Regression of labor force participation rates of all married women and married women, by children ages, 1975-2002 with women-men wage ratios replacing women earnings and men income

\begin{tabular}{|c|c|c|c|c|c|c|c|c|c|}
\hline & $\begin{array}{l}\text { Women-men } \\
\text { Wage Ratio }\end{array}$ & $\begin{array}{c}\text { Unemployment } \\
\text { Rate }\end{array}$ & $\begin{array}{c}\text { Divorce } \\
\text { Rate }\end{array}$ & $\begin{array}{c}\text { Durable } \\
\text { Ratio }\end{array}$ & $\begin{array}{c}\text { Years } \\
\text { at School }\end{array}$ & $\begin{array}{c}\text { Life } \\
\text { Expectancy }\end{array}$ & $\begin{array}{l}\text { Time } \\
\text { Trend }\end{array}$ & $\begin{array}{c}\text { Adjusted } \\
\mathrm{R}^{2}\end{array}$ & D.W. \\
\hline $\begin{array}{l}\text { All married } \\
\text { women }\end{array}$ & $\begin{array}{c}0.14 \\
(0.66)\end{array}$ & $\begin{array}{c}-0.01 \\
(-0.75)\end{array}$ & $\begin{array}{c}0.26 \\
(2.13)\end{array}$ & $\begin{array}{c}0.30 \\
(2.67)\end{array}$ & $\begin{array}{c}1.77 \\
(2.78)\end{array}$ & $\begin{array}{c}-1.55 \\
(-1.35)\end{array}$ & $\begin{array}{c}0.03 \\
(1.77)\end{array}$ & 0.988 & 0.91 \\
\hline \multicolumn{10}{|c|}{ Married women with: } \\
\hline Children $<3$ & $\begin{array}{c}0.01 \\
(0.06)\end{array}$ & $\begin{array}{l}-0.09 \\
(-4.16)\end{array}$ & $\begin{array}{c}0.34 \\
(2.31)\end{array}$ & $\begin{array}{c}0.49 \\
(3.54)\end{array}$ & $\begin{array}{c}2.23 \\
(2.85)\end{array}$ & $\begin{array}{l}-2.01 \\
(-1.43)\end{array}$ & $\begin{array}{c}0.05 \\
(2.34)\end{array}$ & 0.990 & 1.51 \\
\hline Children $<6$ & $\begin{array}{c}-0.08 \\
(-0.36)\end{array}$ & $\begin{array}{l}-0.07 \\
(-3.76)\end{array}$ & $\begin{array}{c}0.31 \\
(2.26)\end{array}$ & $\begin{array}{c}0.60 \\
(4.72)\end{array}$ & $\begin{array}{c}2.32 \\
(3.21)\end{array}$ & $\begin{array}{l}-1.68 \\
(-1.29)\end{array}$ & $\begin{array}{c}0.04 \\
(2.10)\end{array}$ & 0.990 & 1.67 \\
\hline Children $<6-17$ & $\begin{array}{c}0.21 \\
(1.14)\end{array}$ & $\begin{array}{c}-0.07 \\
(-4.38)\end{array}$ & $\begin{array}{c}0.26 \\
(2.52)\end{array}$ & $\begin{array}{c}0.38 \\
(3.92)\end{array}$ & $\begin{array}{c}1.83 \\
(3.34)\end{array}$ & $\begin{array}{c}-1.84 \\
(-1.86)\end{array}$ & $\begin{array}{c}0.03 \\
(1.78)\end{array}$ & 0.992 & 1.24 \\
\hline Children $<18$ & $\begin{array}{c}0.07 \\
(0.41)\end{array}$ & $\begin{array}{c}-0.07 \\
(-4.80)\end{array}$ & $\begin{array}{c}0.29 \\
(2.84)\end{array}$ & $\begin{array}{c}0.44 \\
(4.67)\end{array}$ & $\begin{array}{c}2.04 \\
(3.78)\end{array}$ & $\begin{array}{l}-1.67 \\
(-1.71)\end{array}$ & $\begin{array}{c}0.03 \\
(2.12)\end{array}$ & 0.994 & 1.26 \\
\hline Children $<18+$ & $\begin{array}{c}0.10 \\
(0.43)\end{array}$ & $\begin{array}{l}-0.06 \\
(-2.70)\end{array}$ & $\begin{array}{c}0.30 \\
(2.16)\end{array}$ & $\begin{array}{c}0.41 \\
(3.18)\end{array}$ & $\begin{array}{c}1.90 \\
(2.58)\end{array}$ & $\begin{array}{l}-1.42 \\
(-1.07)\end{array}$ & $\begin{array}{c}0.04 \\
(1.80)\end{array}$ & 0.988 & 0.92 \\
\hline
\end{tabular}

Note: 1. Coefficients are shown below each variable but intercepts are not shown.

2. $\mathrm{t}$-values in parentheses

According to Table 2, women-men wage ratio variable fails to explain the labor force participation of married women. This variable is not statistically significant for all groups of married women and the signs of coefficients vary among sub-groups of married women. The apparent results confirm the previous conclusion that women's wages are not a factor in determining the labor force participation. Unemployment has an expected negative effect with statistical significance, generally at the $5 \%$ level or better. For all married women, it showed a much 
weaker effect compared with those having children at various ages. One implication is that married women with no children must have very weak effects or even a positive effect on the labor force. As the ages of children rise, the coefficients get weaker, implying that married women with young children are more sensitive to unemployment. This is quite true because the younger the children are, the more dependent on the mother. In other words, as the children gets older, they are likely to find jobs and help support the family, thus reducing the need for outside work of the mothers. As expected, divorce rate in this model shows a positive relationship with the labor force participation for all married women and married women separated by children ages with strong statistical significance at the $1 \%$ level but there are no clear patterns among various groups. This result is more superior to that in the first model since it shows the correct signs of coefficients with statistical support. Durable goods to GDP ratio and years at school of women have an expected positive effect with statistical significance, generally at the $1 \%$ level. They perform well in both models. Similar to the first model, coefficients of life expectancy are unexpectedly negative but they are not statistically significant. Again, this puzzle remains in this model. It is plausible to use other variables to replace life expectancy if the study is repeated. The time variable is positive and generally significant at the $5 \%$ level.

In the final analysis, the model with women-men wage ratio is basically preferred to that using both women's earnings and men's income since it generates more crucial variables including divorce rate in explaining the labor force participation. Women's earnings in the first model, women-men wage ratio in the second model and life expectancy in both models, nonetheless, fail to account for the decisions to join the labor force of married women in period 1975 to 2002 in the United States.

\section{Conclusion}

There are three contributions in this study. First, it investigates the factors influencing the labor force participation of married women over time during 1975-2002. Second, along with conventional variables, it includes recent variables that are expected to explain the rising labor force participation of married women. Third, sub-groups of married women, separated by the ages of children, are examined individually to observe if there are any difference in statistical significances and coefficients in determining the labor force participation. The results are as follows. Women's earnings seem not to be a satisfactory factor in determining the married women labor force participation. However, men's income plays a significant role because as it rises, married women need to work in the labor market less and less. Similarly, unemployment rate is another important factor since the married women would have to work more if the unemployment rate increases to sustain the household income. Divorce rate and the durable goods use to GDP ratio are also crucial factors. When divorce rate rises, the married women have to work outside to support themselves and their children. And as durable goods consumption to GDP ratio increases, this implies that the married women have more free time to work in the market. Years at school undoubtedly determine the labor force participation in a positive way. The more years of education, the higher rate of married women to join the labor force. Life expectancy, nonetheless, is not a factor in determining the labor force. This might be due to the problem of correlation with other variables such as death rate and infant mortality rate, which is not examined in this study. It also showed little or almost no variations among different groups of married women, by children ages. This study, however, ignores a significant factor, contraception, due to the unavailability of the data in terms of time series. Contraception use by married women may have influenced the working behaviors in a positive way, so it is left for future study.

\section{References}

(2007). The 2007 Statistical Abstract: The National Data Book. US Census Bureau. http://www.census.gov/compendia/statab/

Aubhik, K. (2004). Why Are Married Women Working More? Business Review, 4, 16-25.

Barry H. (1972). Direct Income and Substitution Effects in Participation Decisions. The Journal of Political Economy, 80, 793-795. http://dx.doi.org/10.1086/259928

Belton M. F., \& George R. (1976). Unemployment and the Labor Force Participation of Married Women: A Simultaneous Model. The Review of Economics and Statistics, 58, 398-406. http://dx.doi.org/10.2307/1935871

Bureau of Economic Analysis. http://www.bea.gov/bea/dn1.htm

Dora, L. C. (2000). From Mill Town to Board Room. The Journal of Economic Perspectives, 14, 101-122. http://dx.doi.org/10.1257/jep.14.4.101

Finis, W. (2000). Growth in Women's Relative Wages and In Inequality among Men: One Phenomenon or Two? The American Economic Review, 2, 444-449. http://dx.doi.org/10.1257/aer.90.2.444 
Glen, C. C. (1960). Married Women in the Labor Force. An Economic Analysis.

http://www.census.gov/

http://www.columbia.edu/ rr91/3802_lectures/womenpower1.htm

Jacob, M. (1962). Labor Force Participation of Married Women. In G. Lewis (Ed.), Aspects of Labor Economics, Universities-National Bureau Conference Series (No. 14). Arno Press: Princeton.

Jeremy, G., Ananth, S., \& Mehmet, Y. (2005). Engines of Liberation. The Review of Economic Studies, 72, 109-133. http://dx.doi.org/10.1111/0034-6527.00326

John, P. (1998). Assortative Mating by Schooling and the Work Behavior of Wives and Husbands. The American Economic Review, 88, 326-329.

Judith, F. (1976). A Comparison of Intercity Difference in the Labor Force Participation Rates of Married Women in 1970 with 1940, 1950, and 1960. Journal of Human Resources, 11, 568-577. http://dx.doi.org/10.2307/145433

Larry, E. J., Rodolfo, E. M., \& Ellen, R. M. (2003). Why Are Married Women Working So Much? Federal Reserve Bank of Minneapolis.

Martha, N. F. (1979). The Labor Force Participation of Turn-of-the-Century Married Women. The Journal of Economic History, 39, 401-418. http://dx.doi.org/10.1017/s0022050700091580

National Center for Health Statistics. http://www.cdc.gov/nchs/nvss.htm

O’Neill, J. A. (1981). A Times-Series Analysis of Women's Labor Force Participation. The American Economic Review, 71, 76-80.

Thomas, A. M. (1961). Factors Determining the Labor-Force Participation of Married Women. Industrial and Labor Relationship Review, 14, 563-577. http://dx.doi.org/10.2307/2520132

US Census Bureau, Historical Income Table. http://www.census.gov/hhes/www/income/histinc/incpertoc.html

US Department of Labor and US Bureau of Labor Statistics. (2005). Women in the Labor Force: a Data Book. US Department of Labor and US Bureau of Labor Statistics.

William, G. B., \& Aidrich, F. T. (1961). The Economics of Labor Force Participation, Princeton.

\section{Copyrights}

Copyright for this article is retained by the author(s), with first publication rights granted to the journal.

This is an open-access article distributed under the terms and conditions of the Creative Commons Attribution license (http://creativecommons.org/licenses/by/3.0/). 